\title{
PROLACTIN MESSENGER RIBONUCLEIC ACID CONCENTRATIONS THROUGHOUT THE OVINE ESTROUS CYCLE ASSESSMENT RELATIVE TO PROLACTIN SERUM AND PITUITARY AMOUNTS
}

\author{
Thomas Landefeld, Vassia Roulia, Ten Bagnell, Thamar Ballard and Inna Levitan \\ Department of Pharmacology, Reproductive Sciences Program, The University of Michigan, Ann \\ Arbor, MI 48109-0626 \\ (Received in final form January 16, 1991)
}

\section{Summary}

Prolactın (PRL) mRNA concentrations were assessed by nucleic acid hybridization assays in pituitaries of ewes representing the defined stages of the ovine estrous cycle. Concomitantly, pituitary and serum PRL concentrations were measured in these ewes using radioimmunoassays It was observed that PRL serum, pituitary and mRNA concentrations tended to increase near the tume of the gonadotropin preovulatory surge, particularly between $24 \mathrm{hrs}$ before behavioral estrus to 5 hours after estrus However, the changes in PRL mRNA, serum and pituitary concentrations were shown not to be statistically significant These data suggest that PRL production during the sheep estrous cycle is maintained without dramatic changes in synthesis or secretion

The pattern of secretion of hormones from the pituitary has been characterized throughout the ovine estrous cycle (1) These hormones (PRL, FSH and LH) all demonstrate a surge prior to ovulation, with FSH showing a secondary surge, after ovulation, in some studies (2-4) This surge of hormones results in ovulation and is therefore critical to reproductive function The gonadotropins clearly play an important role in the development of the ovanan events necessary for the release of the ovum However, the role of the PRL surge at this time is not as well defined especially since PRL has a plethora of effects including cell metabolism. Furthermore, PRL synthesis/secretion regulation is quite complex First, numerous effectors are involved in secretion (5-12) Second, PRL gene expression is also under regulation of several effectors $(13-20)$.

Recent work from our laboratory has reported the pattern of gonadotropın subunit mRNAs throughout the estrous cycle, thereby providing information as to the contribution of biosynthesis to the gonadotropin secretory process (21) A divergent pattern of LH $\beta$ and FSH $\beta$ mRNAs was observed, particularly around the time of the preovulatory surge, providing support for differential regulation of these subunits at a pretranslational level Similar data have not been reported for PRL mRNA concentrations throughout the ovine cycle; however, a report by Haisenleder et al (22) demonstrated changes in PRL mRNA amounts during the 4-day rat estrous cycle The changes were observed throughout the rat cycle with the most significant (7fold increase) ones seen during diestrus Interestingly, this increase was not associated with a change in serum PRL At the time of the surge on proestrus, PRL mRNA amounts rose concomitantly. Thus it appeared that different regulatory mechanisms may be involved at different tumes of the cycle

Since some studies have reported a rise in serum PRL during the ovine estrous cycle $(1,5,6,11,23-25)$ with a particular emphasis on the times surrounding the gonadotropin surge, this study was designed to assess mRNA changes and as a result, possibly elucidate a 
relationship between PRL synthesis and the serum concentrations observed durng the estrous cycle.

\section{Materials and Methods}

Anumals: Estrous cycles of Suffolk ewes ( $n=5-8$ /group) were synchronized during the breeding season (November) with progesterone implants (26) The ewes were then kalled at the selected tumes representing the major phases of the cycle (27) Briefly, these included luteal phases (designated as Day 5, 8 and 12), a follicular phase (1 e behavioral estrus minus $24 \mathrm{hrs}$ ), and preovulatory surge tımes (1 e behavioral estrus plus $5,15,25$ and $50 \mathrm{hrs}$ )

For purposes of onentation relative to the estrous cycle ( $\approx 16$ days in length), the groups Day 8, Day 12, E-24, E+5, E+15, E+25, E+50 and Day 5 are represented on the X-axis as -8, $-4,-1,02,06,10,21$ and 5, respectuvely, in Figures 1, 2 and 3

Serum Hormone Analyses: Serum samples $(5 \mathrm{ml})$ were collected by jugular venipuncture every 4 hours beginning on Day 14 and then hourly after the onset of behavioral estrus $(26,27)$ These samples were assayed for PRL in 20-200 $\mu$ l aliquots in a radioimmunoassay described by Davis et al (24) The sensitivity of this assay was $03 \mathrm{ng}$ /tube using oPRL (NIH P-S-88) as the standard Pituitary PRL concentrations were also assessed in this assay Sample volumes (25$100 \mu \mathrm{l})$ of a $1: 10,000$ dilution of pituitary homogenate $(15,000 \mathrm{x}$ g supernatant) were used The homogenization buffer included $005 \mathrm{M}$ Tris- $\mathrm{HCl}, \mathrm{pH} 78,25 \mathrm{mM} \mathrm{KCl}, 5 \mathrm{mM} \mathrm{MgCl}, 7 \mathrm{mM}$ $\beta$-mercaptoethanol, and $880 \mathrm{mM}$ sucrose

RNA Extractions. Glands were removed within 15 minutes of death and frozen in liquid nitrogen until RNA extractions were performed Total pituitary RNA was extracted by one of two methods, phenol (27) or guanıdinium isothiocyanate $(21,26)$ Similar $A_{260} / A_{280}$ ratios (1 e 1 7-1 9) were observed for the RNA preparations regardless of the method of extraction.

cRNA Preparation and Labeling. PRL cDNA in the pGEM vector (Promega, Madison WI) was prepared by subcloning a bovine PRL cDNA fragment ( $580 \mathrm{bp}$ ) into the Hinc II site of pGem 3 (Dr R A Maurer, University of Iowa) The plasmid was lineanzed with Bam HI or Hind III and transcription was performed on the linearized DNA using SP6 or T7 RNA polymerases as described previously (21)

RNA Quanutation Specific PRL mRNA amounts were assessed in total RNA preparations using a solution hybridization assay as previously described (21) Linearity was observed in standard curves (using the sense mRNA strand) between 2 and $30 \mathrm{pg}(\approx 001-020$ fmole) with a sensitivity of $\approx 002$ fmoles and nonspecific binding averaging $2 \%-5 \%$ of total counts Intraassay coefficient of variations ranged from $10 \%-15 \%$. Concentration curves were performed for individual RNAs from each group to test for parallelism with that obtained for the standard curve Once the optımal amount was determined, samples were assayed in triplicate. Data were analyzed by one-way analysis of variance

\section{$\underline{\text { Results }}$}

mRNA Amounts. PRL mRNA concentrations throughout the ovine estrous cycle are shown in Figure 1. Although there appeared to be a trend for these values to increase near the time of the onset of estrus ( 1 e E-24 and E+5), these increases were not statistically significant A similar trend was observed for LH $\beta$ mRNA near the tume of the preovulatory gonadotropin surge (21)

Serum PRL Concentrations PRL serum concentrations $(\mathrm{ng} / \mathrm{ml})$ durng the ovine estrous cycle are shown in Figure 2 Again, an increase in serum PRL appears to occur in the E-24 group (coinciding with the time of the gonadotropin surge, 21,26, and PRL mRNA concentrations, Fig 1), however, due to the large variability associated with this group, the increase is not statistically significant This vanability is most likely due to differences among the ewes relative to the changes in serum PRL in each ewe 


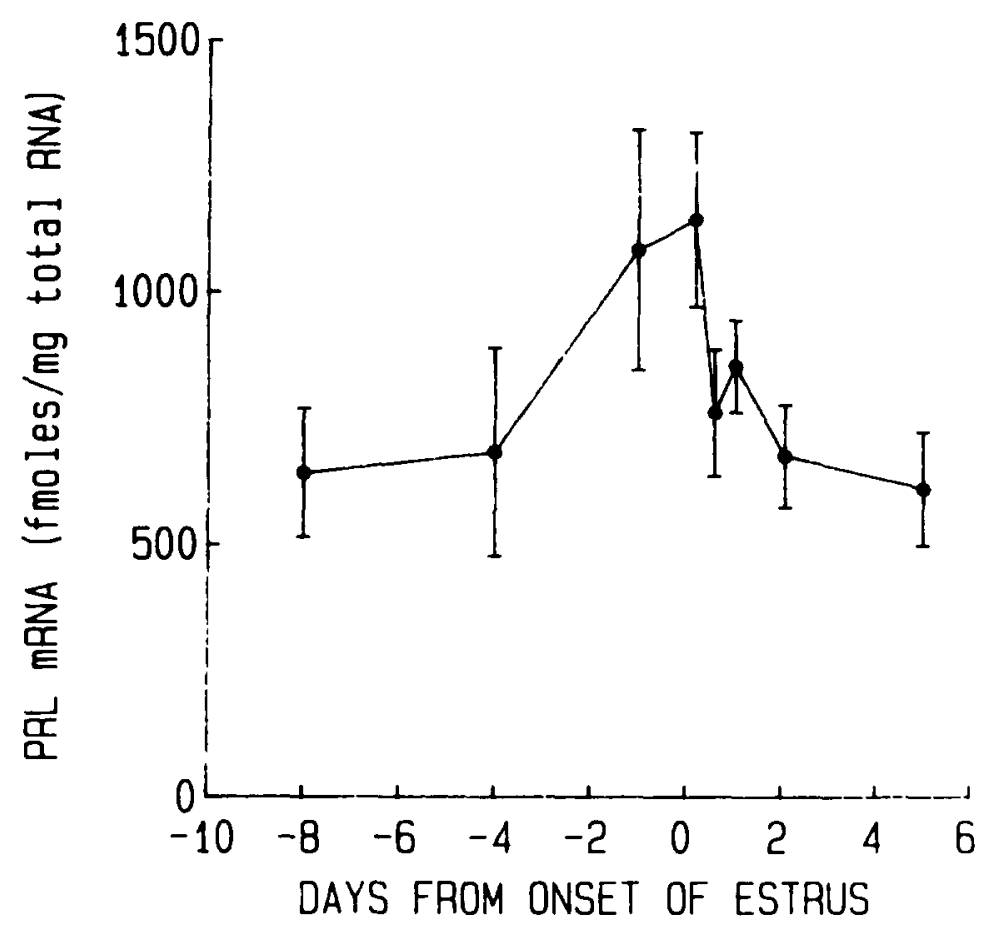

FIG 1

PRL mRNA concentrations (fmoles/mg total RNA) throughout the ovine estrous cycle Values represent mean $\pm S E$ of each group as described in Methods and Materials

Pituitary PRL Concentrations The concentrations of PRL in the pituitaries of the ewes during the estrous cycle are depicted in Fig 3 Again, there are no significant changes in these amounts during the cycle, although the values tended to increase between the late follicular phase (i e E$24)$ and the early stages of the surge ( 1 e E+5)

\section{Discussion}

The function of PRL in the ovine estrous cycle has not been clearly elucidated Based on the metabolic effects of PRL and possible actions in the ovary, a role in reproduction is quite feasible. Some evidence for a nse in PRL near the tume of the preovulatory gonadotropin surge is avalable, although the data do not support a well-defined peak as seen with the gonadotropins $(5-7,11,23,24)$. As part of the delineation of the role of this hormone, it is important to establish the cellular/molecular mechanisms involved at this time and then to examine the effects of individual modulations of PRL synthesis and secretion In this study, PRL mRNA concentrations were assessed throughout the ovine estrous cycle at tumes representative of the major stages of reproduction (1 e. luteal, follicular and surge), with a particular emphasis around the preovulatory surge and then examined relative to PRL pituitary and serum concentrations As such, the overall process of PRL production during the estrous cycle can be investigated

Although there appeared to be a trend for increasing PRL mRNA concentrations near the time of the gonadotropin preovulatory surge (1 e $24 \mathrm{hrs}$ before estrus and $5 \mathrm{hrs}$ after estrus), these changes were not statistically significant We had observed similar results with LH $\beta$ mRNA concentrations during the cycle, and, in particular, near this time. Although there are no 


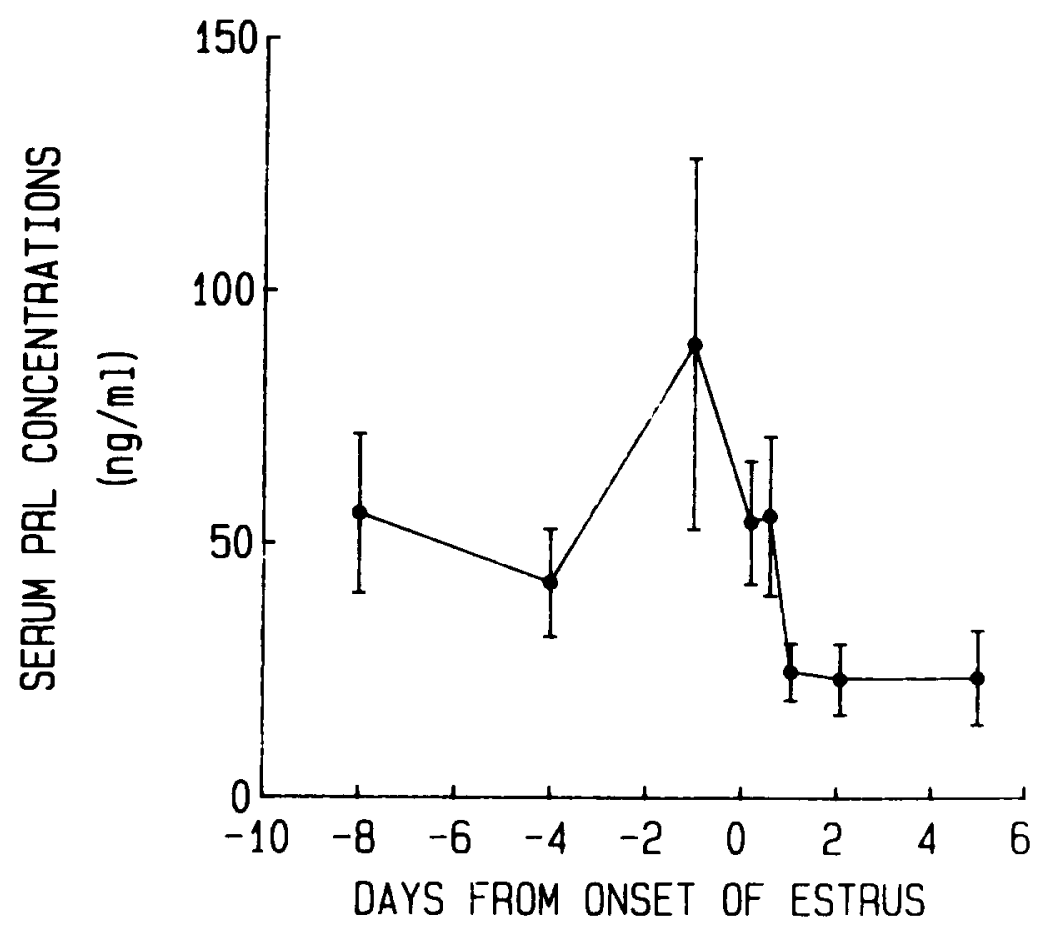

FIG 2

Serum PRL concentrations (ng/ml) throughout the ovine estrous cycle Values represent mean $\pm S E$ of each group

published data on PRL mRNA concentrations during the ovine cycle, Haisenleder et al (22) reported changes in PRL mRNA amounts during the rat estrous cycle The major changes observed in that study were during diestrus where a decrease in the morning was followed by a 7-fold increase by evening

Relative to secretion, a statistically significant increase was not seen for PRL, even near the time of the gonadotropin surge. However, as with PRL mRNA concentrations, there was a trend for increased PRL serum amounts near this time (1 e $24 \mathrm{hrs}$ before behavioral estrus) It is important to note that the data on serum PRL (Fig 2) do not represent a continuous bleeding protocol, but rather the mean serum PRL concentrations for each group of ewes at the tıme of kıll. As such, differences among anımals relatıve to any changes in PRL will contribute to the variability, as evidenced by the SEM for the E-24 group Accordingly these data will influence the statistical significance of the differences As mentioned earlier, some data in the hterature support a PRL "surge" although it is not well defined

The pituitary PRL content pattern again suggested a trend for an increase near the time of estrus (1 e E+5) despite the lack of statistical significance. However, it is also possible to interpret the data as a fall in PRL amount durng the late luteal phase of the cycle, since these values are more than $50 \%$ lower than values seen during the times of the cycle Since there is no previously published data on pituitary PRL content during the sheep cycle, there is no direct basis for comparison However, when one examines the changes in PRL content in the rat cycle (Haisenleder et al , 1989), an increase does occur shortly before the serum PRL rise This is at $1200 \mathrm{~h}$ on proestrus, a tıme that is somewhat simılar to $\mathrm{E}+50$ In fact, except for the amounts 


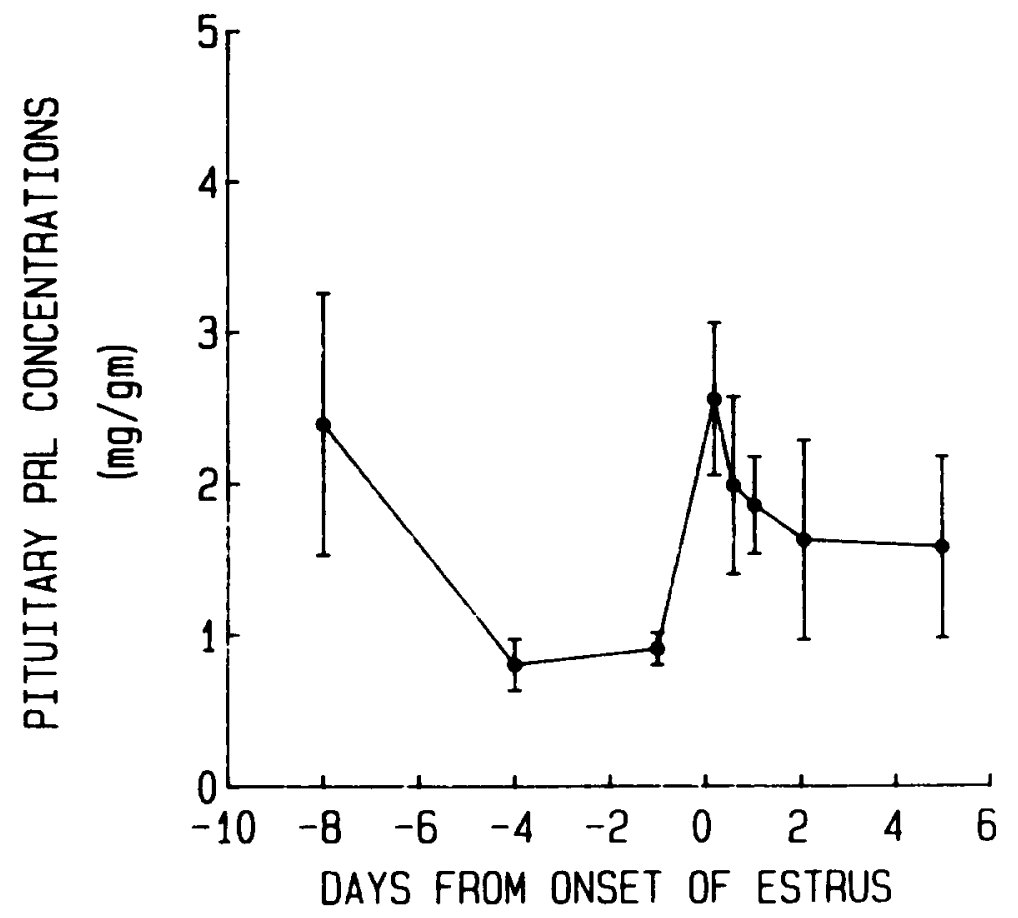

FIG 3

Pituitary PRL concentrations (mg/gm) throughout the estrous cycle Values represent mean $\pm S E$ of each group

seen in the Day 8 group (sheep), the pattern of PRL content between the two species appear quite simlar.

In conclusion, this is the first published report on the amounts of PRL mRNA and pituitary PRL content throughout the ovine estrous cycle Furthermore, by measuring serum PRL concentrations in these ewes, it is possible to examine three parameters that are most directly involved in the production of PRL (1.e synthesis, storage/processing, secretion) Generally, all three of these parameters followed similar patterns, in that a trend for an increase was suggested near the tume of estrus. However statistical significance was not observed in these groups throughout the estrous cycle. The data suggest that PRL production is maintained throughout the estrous cycle without major changes in either synthesis or secretion

\section{Acknowledgements}

The authors are indebted to Mr Doug Doop for his help with the animals and to Ms Virgie Bright for her help with the assays. We also want to thank Marjory Falconer and Debbie Block for the preparation of this manuscript and Dr Dan Haisenleder for his helpful comments This work was supported by NIH grants HD12016 and 18258

\section{REFERENCES}

1. D T BAIRD, A.S MCNEILLY, J Reprod. Fert (Suppl) 30 119-133 (1981)

2. M L'HERMITE, G D NISWENDER, L E REICHERT JR, A R MIDGLEY JR , B1ol. Reprod 6 325-332 (1972) 
3 G D NISWENDER, R.T MOORE, A.M AKBAR, T M NETT, M A DIEKMAN, B1ol Reprod. 13 381-388 (1975)

4 J R. MCNEILLY, A S MCNEILLY, J S WALTON, F J CUNNINGHAM, $\mathrm{J}$ Endocrinol 70 69-79 (1976)

5 G D BRYANT, F C GREENWOLD, G KAHN, J MARTINET, R DENAMUR, J Endocnnol 51 405-406 (1971)

6 H M FRASER, A S MCNEILLY, Endocrınology 111 1964-1973 (1982)

7 D L DAVIS, M L BORGER, J Anım Sc1 38 795-802 (1984).

8 H ABE, D ENGLER, M E MOLITCH, J BOLLINGER-GRUBER, S REICHLIN, Endocrinology 116 1383-1390 (1985)

9 W J DEGREEF, W KLOOTWIJK, B KARELS, T J VISSER, J Endocrinol 105 107-112 (1985)

$10 \mathrm{~K}$ NIKOLICS, A J MASON, E SZONYI, J RAMACHANDRAN, PH SEEBURG, Nature $316511-517$ (1985)

11 G.B THOMAS, J T CUMMINS, L CAVANAGH, I J CLARKE, J Endocnnol 111 425-431 (1986)

12 C A JOHNSTON, A NEGRO-VILAR, Endocrinology 122 341-350 (1988)

13 R A MAURER, Nature 294 94-97 (1981)

14 R A MAURER, J B1ol Chem 257 2133-2136 (1982a)

15 R A MAURER, Endocrinology 110 1507-1514 (1982b)

16 R A MAURER, DNA 4 1-9 (1985)

17 G H MURDOCH, R FRANCO, R M EVANS, M G ROSENFELD, J Biol Chem 258 $15329-15335$ (1983)

18 B A. WHITE, F C BANCROFT, J Biol Chem 258 4618-4622 (1983)

19 A J CARRILLO, T B. POOL, Z D SHARP, Endocrnology 116 202-206 (1985)

20 J D. SCHULL, J GORSKI, Endocrinology 116 2456-2462 (1985)

21. K LEUNG, K.E KIM, R A MAURER, T D LANDEFELD, Mol Endo $\underline{2}$ 272-276 (1988)

22. D J HAISENLEDER, G A ORTOLANO, T D LANDEFELD, S M ZMEILI, J C MARSHALL, Endocrinology 124 2023-2028 (1989)

23 J J REEVES, A ARIMURA, A V SCHALLY, Proc Soc Exp Biol Med 134 938-942 (1970).

24. S.L DAVIS, L E REICHERT, G D NISWENDER, B1ol. Reprod 4 145-153 (1971)

25 A S MCNEILLY, D.T BAIRD, J Reprod Fertll 69 559-568 (1983)

26 T.D. LANDEFELD, J KEPA, J B1ol Chem. 259 12817-12820 (1984)

27 T D LANDEFELD, J KEPA, F J KARSCH, Proc Natl Acad Scı USA $\underline{81}$ 1322-1326 (1984). 